\title{
PENGARUH METODE MIND MAPPING TERHADAP MINAT BELAJAR BIOLOGI KONSEP MONERA SISWA KELAS X SMA
}

\author{
Harfika ${ }^{1}$ \\ Universitas Muhammadiyah Makassar, fharfika14@gmail.com \\ Rahmatia Thahir ${ }^{2}$, Hilmi Hambali ${ }^{3}$ \\ Universitas Muhammadiyah Makassar, rahmatiah.thahir@unismuh.ac.id, \\ hilmihambali@unismuh.ac.id
}

\begin{abstract}
Abstrak
Tujuan dari penelitian ini adalah untuk mengetahui pengaruh metode mind mapping terhadap minat belajar biologi konsep monera pada siswa kelas X di SMAN 9 Makassar. Jenis penelitian ini adalah eksperimen semu (quasy eksperimen) dengan bentuk desain Posttest Only Control Design. Populasi dalam penelitian ini yaitu seluruh siswa kelas X Mia sebanyak 8 kelas dengan jumlah 274 siswa. Sampel dalam penelitian ini yaitu siswa kelas X MIA 7 sebanyak 32 siswa sebagai kelas eksperimen dan siswa kelas X MIA 6 sebanyak 32 sebagai kelas kontrol. Pengambilan sampel menggunakan teknik Random Sampling. Instrumen yang digunakan dalam penelitian berupa angket terdiri dari 25 pernyataan yang sudah di validasi. Teknis analisis data yang digunakan adalah Independent Samples T-test. Hasil uji analisis Independent Samples T-test pada minat belajar siswa didapatkan nilai Sig (2-tailed) $0,008<0,05$. Hal ini berarti $\mathrm{H}_{0}$ di tolak dan $\mathrm{H}_{1}$ diterima atau dengan kata lain ada pengaruh penerapan metode mind mapping terhadap minat belajar biologi konsep monera pada siswa kelas X MIA di SMA Negeri 9 Makassar.
\end{abstract}

Abstract
The purpose of this study was to determine the effect of mind mapping methods on the interest learning of the monera concept biology in class $X$ students at SMAN 9 Makassar. This type of research is quasy experiment (quasy experiment) with the design of the Posttest Only Control Design. The population in this study were all students of class X Mia as many as 8 classes with a total of 274 students. The sample in this study were 36 students of Class X MIA 7 as the experimental class and 35 students of Class X MIA 6 as the control class. Sampling using the Random Sampling technique. The instrument to use in the study was a questionnaire consisting of 25 statements that had been validated. The data analysis technique used was the Independent Samples Ttast. The results of the analysis of the Independent Samples T-test on students' interest in learning Sig (2-tailed) $0.008<0.05$. This means that $\mathrm{HO}$ is rejected and $\mathrm{H} 1$ is accepted or the mind mapping method influences on the interest learning of the monera concept biology in class X MIA students at SMA Negeri 9 Makassar.

Kata kunci: metode Mind mapping, Minat belajar 


\section{PENDAHULUAN}

Pendidikan merupakan dimensi utama dapat menciptakan manusia berilmu, berpengatuan dan berbudaya. Menyadari begitu pentingnya pendidikan dalam menentukan kualitas manusia untuk mampu bersaing dengan manusia atau SDM negara lain, lembaga pendidikan berusaha untuk menciptakan sistem pendidikan yang efektif dan efisien. Sistem pendidikan di Indonesia adalah mengacu pada Sistem Pendidikan Nasional yang merupakan sistem pendidikan yang akan membawa kemajuan dan perkembangan bangsa.

Pendidikan yang diawali dengan kebijakan otonomisasi pada satuan pendidikan, dan berujung pada perluasan kewenangan guru dalam mengembangkan pembelajaran. Dalam kegiatan pembelajaran, guru berperan sebagai motivator dan fasilitator. Peran guru sebagai motivator adalah memberi motivasi kepada siswa agar melakukan kegiatan belajar dengan kehendak sendiri tanpa adanya tekanan dan paksaan dan sesuai dengan tujuan belajar yang akan dicapai. Guru sebagai fasilitator adalah menfasilitasi siswa agar dapat belajar dengan mengembangkan prestasi yang dimilikinya dengan cara menciptakan lingkungan belajar yang menarik agar siswa tertarik dan berperan aktif mengikuti pembelajaran.

Guru sebagai salah satu komponen penting yang menentukan keberhasilan siswa dalam kegiatan belajar mengajar harus pandai menciptakan situasi dan kondisi mengajar yang menarik sehingga siswa tidak bosan dalam mengikuti pembelajaran. Guru harus mampu membangkitkan minat belajar siswa karena dapat berpengaruh pada hasil belajar yang dicapai siswa, harus terampil dalam mengemas pelajaran yang dapat membantu memecahkan permasalahan, memberikan ide-ide baru, mengembangkan suatu gagasan serta dapat mengambil keputusan terhadap situasi yang berkaitan dengan pembelajaran sehingga dapat menarik minat belajar siswa dan meningkatkan hasil belajar siswa.

Berdasarkan hasil wawancara salah seorang guru di SMA Negeri 9 Makassar, diketahui bahwa siswa cenderung pasif dalam menerima materi pembelajaran. Hal ini disebabkan karena pembelajaran di kelas didominasi penggunaan metode pembelajaran yang belum bersifat variatif. Pada proses pembelajaran guru 
lebih mendominasi menggunakan metode ceramah di kelas. Metode yang digunakan pada saat mengajar hanya menitikberatkan pada guru serta pembelajaran dilaksanakan hanya sebatas memberikan penjelasan terkait konsep-konsep yang diajarkan tanpa memberi kesempatan kepada siswa untuk berperan aktif dalam mengikuti pembelajaran.

Hal tersebut menyebabkan minat belajar siswa rendah sehingga mengakibatkan pemahaman siswa terhadap materi yang diajarkan tidak maksimal. Ketika siswa mengerjakan soal ulangan hasil yang didapatkan tidak sesuai dengan harapan. Kurang ketertarikan siswa terhadap minat belajar berpengaruh terhadap tingkat kelulusan yang dicapai siswa, dimana masih terdapat $22 \%$ siswa yang tidak lulus KKM yang telah ditentukan di sekolah yaitu 75. Hal ini akan menghambat ketercapaian tujuan pembelajaran. Dimana tujuan pembelajaran yang siswa dapatkan tidak akan maksimal karena kurangnya prestasi siswa yang secara umum berawal dari minat belajar yang rendah mengatarkan pada keinginan belajar yang sangat rendah. Oleh karena itu diperlukan suatu stimulus yang berasal dari metode pembelajaran yang digunakan oleh guru untuk menarik minat belajar siswa.

Guru harus memikirkan bagaimana cara untuk jalan atau solusi yang ditempuh dalam merencanakan, melaksanakan, dan mengukur suatu keberhasilan pembelajaran sesuai yang diinginkan. Ada beberapa cara yang digunakan dalam merencanakan hal tersebut salah satunya dengan metode. Metode adalah seperangkat prosedur yang bisa ditempuh daam pelaksanaan pembelajaran sehingga cocok atau sesuai dengan asumsi dasar yang dipikirkan. Alternatif solusi yang dapat dilakukan adalah dengan mengubah metode pembelajaran menjadi lebih menarik minat belajar siswa. Salah satu metode yang dapat digunakan adalah metode Mind Mapping. Mind Mapping adalah salah satu bentuk pembelajaran yang digunakan untuk melatih kemampuan menyajikan isi materi pelajaran dengan pemetaan pikiran (Mulyatiningsih, 2014).

Metode mind mapping merupakan cara yang paling mudah untuk memasukkan informasi kedalam otak, dan untuk mengambil informasi dari otak (Abtholulbihar, 2018). Cara ini adalah cara yang paling kreatif dan 
efektif dalam membuat catatan sehingga boleh dikatakan mind mapping benarbenar memetakan pikiran anda. Oleh karena itu metode mind mapping menjadi solusi yang dipilih oleh penulis untuk membantu siswa dalam memahami materi monera.

Penerapan metode Mind Mapping dapat menarik minat belajar. Minat belajar perlu mendapatkan perhatian khusus karena minat belajar merupakan salah satu faktor penunjang keberhasilan proses belajar. siswa akan belajar dengan baik apabila mempunyai minat belajar yang besar. Jika memiliki keinginan untuk belajar yang tinggi, ia akan cepat mengingat dan mengerti apa yang ia pelajari.

Sejalan dengan penelitian yang dilakukan oleh Nazliah-Rahmi, Harahap, \& Hasibuan (2019) mind mapping adalah teknik memcatat yang menyenangkan karena melibatkan warna, gambar, dan kata. Hal ini pula didukung oleh teori Swadarma (2013) yang menyatakan bahwa Mind Mapping merupakan cara belajar yang efektif, efisien, kreatif, menarik, mudah dan berdaya guna karena dilakukan dengan cara memetakan pikiran- pikiran kita.

Berdasarkan hal tersebut maka peneliti merasa perlu melakukan penelitian tentang Pengaruh Metode Mind Mapping terhadap Minat Belajar Biologi konsep Monera pada siswa Kelas X di SMAN 9 Makassar.

\section{METODE PENELITIAN}

Jenis penelitian yang digunakan dalam penelitian ini yaitu quasy eksperimen (eksperimen semu). Quasy eksperimen yaitu penelitian yang digunakan untuk mengetahui pengaruh dari suatu perlakuan yang dilakukan terhadap suatu kondisi tertentu. Desain yang digunakan dalam penelitian ini adalah Posttest Only Control Design. Menurut Sugiyono (2016), bentuk Posttest Only Control Design digambarkan pada tabel 1 dibawah ini.

\begin{tabular}{ccc}
\multicolumn{4}{c}{ Tabel 1. Desain Penelitian } \\
\hline A & $\mathrm{X}$ & $\mathrm{O}_{2}$ \\
\hline B & - & $\mathrm{O}_{4}$ \\
\hline
\end{tabular}

Keterangan :
$\mathrm{A}=$ Kelas Eksperimen
$\mathrm{B}=$ Kelas kontrol
$\mathrm{X}=$ Penerapan metode mind mapping
- $=$ Penerapan metode pembelajaran tanpa minp mapping
$\mathrm{O}_{2}=$ Posttest kelas eksperimen
$\mathrm{O}_{4}=$ Posttest kelas kontrol

Adapun Variabel Penelitian dalam penelitian ini yaitu Variabel 
bebas (Independen) dalam penelitian ini adalah metode mind mapping. Sedangkan Variabel terikat (Dependen) dalam penelitian ini adalah Minat dan Hasil Belajar. Populasi dalam penelitian ini yaitu seluruh siswa kelas X MIA SMA Negeri 9 Makassar tahun ajaran 2019-2020 yang berjumlah 274 orang dari 8 kelas. Sampel penelitin yaitu siswa kelas X MIA 7 sebanyak 32 siswa sebagai kelas ekperimen dan X MIA 6 sebanyak 32 siswa sebagai kelas kontrol yang di pilih dengan teknik pengambilan sampel menggunakan teknik random sampling. Random sampling yaitu teknik pengambilan sampel secara acak.

Definisi Operasional Variabel dengan menterjemahkan batasan setiap variabel yang dimaksud yaitu Mind mapping merupakan cara yang memudahkan siswa memahami materi yang berupa ringkasan singkat dalam bentuk peta pikiran, dan Minat belajar merupakan tolak ukur siswa dilihat dari ketertarikan dalam mengikuti proses pembelajaran.

Penelitian ini dilaksanakan di SMA Negeri 9 Makassar, jalan karunrung raya, kecamatan rappocini, kota makassar, sulawesi selatan yang berlangsung pada bulan September sampai November tahun 2019.

Instrumen penelitian yang berupa angket berisi 24 pernyataan dibagikan kepada siswa pada akhir pertemuan atau post test. Instrumen Angket yang digunakan untuk memperoleh data mengenai minat belajar siswa terhadap ketertarikan terhadap proses pelajaran. Indikator dari angket minat belajar siswa meliputi : perasaan senang, perhatian siswa, ketertarikan dalam belajar, serta keterlibatan siswa.

Teknik pengambilan data penelitian ini diperoleh Kuesioner (angket) ini digunakan untuk mengetahui respon siswa saat diterapkan metode mind mapping selama pembelajaran. Kuesioner ini berisi tanggapan siswa setelah mengalami sendiri proses pembelajaran dengan menggunakan metode mind mapping. Juga dengan dokumentasi sebagai alat pengumpulan data tertulis atau tercetak tentang fakta-fakta yang akan dijadikan sebagai bukti fisik penelitian dan hasil penelitian yang merupakan alat pendukung kegiatan penelitian.

Teknik analisis data terbagi atas dua yaitu analasis deskriptif dan analisis 
inferensial. Analisis data deskriptif Analisis deskriptif adalah teknik analisis yang digunakan untuk menganalisis data dengan cara mendeskripsikan atau menggambarkan data yang telah terkumpul sebagaimana adanya tanpa bermaksud membuat kesimpulan yang berlaku untuk umum atau generalisasi. Teknik ini mendeskripsikan data yang sudah ada dan disajikan dalam bentuk tabel, atau disajikan dalam bentuk lainnya beserta uraian-uraian singkat. Adapun pengkategorian minat belajar dapat dilihat pada tabel 2 berikut ini.

Tabel 2. Pengkategorian Minat Belajar

\begin{tabular}{cc}
\hline Interval Nilai & Keterangan \\
\hline $81-100$ & Sangat Tinggi \\
\hline $61-80$ & Tinggi \\
\hline $41-60$ & Cukup \\
\hline $21-40$ & Rendah \\
\hline $0-20$ & Sangat Rendah \\
\hline
\end{tabular}

Sumber : Ridwan (2009)

Sedangkan analisis data inferensial meliputi pengujian persyaratan yaitu uji normalitas dan uji homogenitas, serta uji hipotesis dengan bantuan program SPSS (Statistical Product and Service Solutions) versi 25.0 dengan taraf signifikansi $(\alpha)=0,05$. Uji normalitas bertujuan untuk mengetahui apakah data kita berdistribusi normal atau tidak. Data dapat dikatakan berdistribusi normal, jika angka signifikan $(\mathrm{Sig})>0,05$. Uji normalitas yang digunakan adalah dengan uji Kolmogorov-Smirnov.

Uji homogenitas bertujuan untuk mengetahui apakah kedua kelompok memiliki varians yang sama atau tidak. Uji homogenitas dilakukan dengan uji Homogeneity of Varience Test. Kriterianya adalah signifikan untuk uji dua sisi jika hasil perhitungan lebih besar dari $>0,05$ berarti variansi pada setiap kelompok sama (homogen). Uji hipotesis dilakukan dengan tujuam untuk mengetahui hipotesis kita diterima atau ditolak.

Uji hipotesis dilakukan dengan cara perhitungan sehingga pada setiap rumus masalah dapat ditemukan jawabannya secara kuantitatif untuk mengetahui hipotesis diterima atau ditolak atau mengetahui apakah terdapat perbedaan sebelum dan setelah diberi perlakuan.

$\mathrm{H}_{1} \quad$ : Ada pengaruh metode mind mapping terhadap minat belajar biologi konsep monera pada siswa kelas X SMA Negeri 9 Makassar.

$\mathrm{H}_{0} \quad$ : Tidak ada pengaruh metode mind mapping terhadap hasil belajar biologi konsep monera 
pada siswa kelas X SMA Negeri

9 Makassar.

Jika sig $>\alpha$, maka $\mathrm{H}_{1}$ ditolak.

Jika sig< $<\alpha$, maka $\mathrm{H}_{1}$ diterima.

Taraf signifikan untuk menguji hipotesis dalam penelitian ini menggunakan taraf kepercayaan 95\% atau $\alpha=0,05$ atau Nilai Sig $<0,05$. Uji hipotesis menggunakan uji analisis Independent Samples T-test denga bantuan SPSS versi 25.

\section{HASIL DAN PEMBAHASAN}

Data hasil analisis deskriptif menunjukkan deskripsi skor minat belajar siswa pada masing-masing kelompok penelitian. Berdasarkan hasil analisis deskriptif, skor minat belajar siswa pada kelas X MIA 7 sebagai kelas eksperimen yang diajar menggunakan metode mind mapping dan X MIA 6 sebagai kelas kontrol yang diajar menggunakan metode ceramah di SMA Negeri 9 Makassar yang dapat dilihat pada tabel 3 berikut ini.

Tabel 3 Data Statistik Skor Minat Belajar Siswa Kelas Eksperimen dan Kontrol

\begin{tabular}{ccc}
\hline $\begin{array}{c}\text { Deskripsi } \\
\text { Data }\end{array}$ & $\begin{array}{c}\text { Kelas } \\
\text { Eksperimen }\end{array}$ & $\begin{array}{c}\text { Kelas } \\
\text { Kontrol }\end{array}$ \\
\hline $\begin{array}{c}\text { Jumlah } \\
\text { Sampel }\end{array}$ & 32 & 32 \\
\hline Mean & 91,2 & 82,4 \\
\hline $\begin{array}{c}\text { Skor } \\
\text { Minimum }\end{array}$ & 66 & 61 \\
\hline $\begin{array}{c}\text { Skor } \\
\text { Maksimum }\end{array}$ & 116 & 115 \\
\hline
\end{tabular}

Berdasarkan tabel 3 di atas, data statistik skor minat belajar siswa pada kelas eksperimen didapat nilai terendah 66 dan nilai tertingi 116 dengan nilai rata-rata 91,2. Pada kelas kontrol didapat nilai terendah 61 dan nilai tertinggi 115 dengan nilai rata-rata 82,4. Hal ini menunjukkan bahwa rata-rata skor minat belajar siswa pada kelas eksperimen lebih tinggi dari pada kelas kontrol.

Data skor minat belajar siswa dikelompokkan ke dalam kategori lima skala yaitu kategori sangat rendah, rendah, cukup, tinggi dan sangat tinggi, maka diperoleh distribusi frekuensi dan persentase minat belajar siswa pada kelas eksperimen X MIA 7 dan kelas kontrol X MIA 6 di SMA Negeri 9 Makassar diuraikan pada tabel 4 dibawah ini.

Tabel 4 Data Distribusi Frekuensi Minat Belajar Siswa pada Kelas Eksperimen dan Kelas Kontrol Posttest

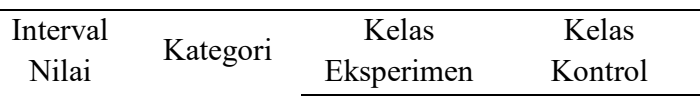




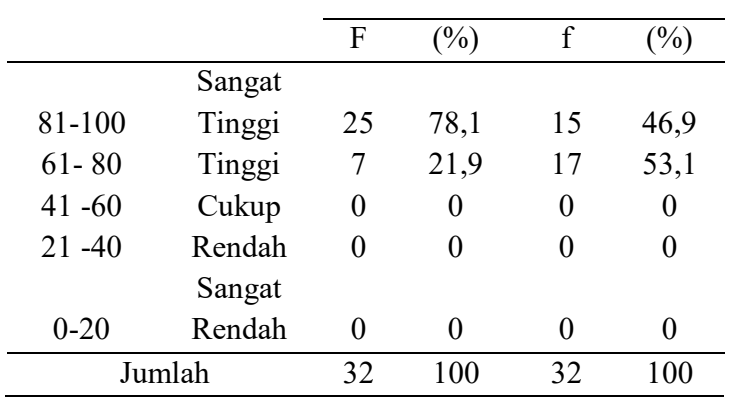

Berdasarkan tabel 2 di atas data distribusi dan persentase minat belajar siswa pada kelas eksperimen terdapat 25 siswa $(78,1 \%)$ memperoleh nilai pada kategori sangat tinggi, 7 siswa (21,9\%) kategori tinggi dan tidak ada siswa yang memperoleh nilai dengan kategori cukup, rendah dan sangat rendah. Pada kelas kontrol 15 siswa (46,9\%) yang mendapat nilai dengan kategori sangat tinggi dan 17 siswa $(53,1 \%)$ kategori tinggi serta tidak ada siswa yang memperoleh nilai dengan kategori cukup, rendah dan sangat rendah.

Berdasarkan data tersebut menunjukkan bahwa pada kelas eksperimen yang diajarkan menggunakan metode mind mapping lebih banyak siswa yang memperoleh nilai pada kategori sangat tinggi $(78,1 \%)$ dari pada kelas kontrol (46,9\%). Maka dapat disimpulkan bahwa pada kelas eksperimen minat belajar siswa setelah diajarkan menggunakan metode mind mapping lebih tinggi pengaruhnya dari pada kelas kontrol.

Selanjutnya, untuk lebih memudahkan dalam melihat kategori minat belajar siswa pada kelas eksperimen dan kelas kontrol, maka disajikan dalam bentuk diagram batang pada gambar 1 sebagai berikut:

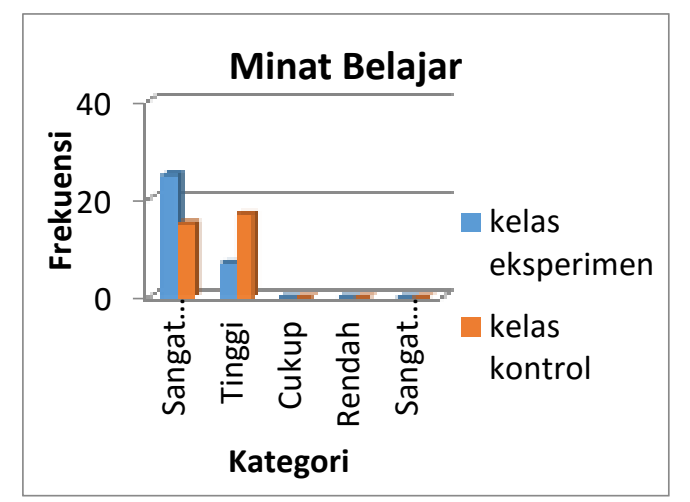

Gambar 1 Diagram kategori Minat Belajar Siswa Kelas Eksperimen dan Kelas Kontrol

Berdasarkan gambar 1 diatas, kategori minat belajar pada kelas eksperimen yang diajar menggunakan metode mind mapping minat belajar siswa sangat tinggi dibandingkan minat belajar siswa kelas kontrol yang diajar menggunakan metode ceramah.

Selanjutnya, berdasarkan hasil analisis data inferensial yang terlebih dahulu dilakukan uji prasyarat yaitu uji normalitas minat belajar menggunakan uji Kolmogorov-Smirnov diperoleh nilai sig $0,192>0,05$ berarti data ini berdistribusi normal. Dan uji homogenitas dengan menggunakan 
Homogenity of varience test diperoleh nilai sig $0,553>0,05$ berarti data ini homogen. Selajutnya untuk menguji hipotesis maka data dianalisis menggunakan Independent Samples $T$ test diperoleh nilai sig $0,008<0,05$ yang berati terdapat pengaruh penggunaan metode mind mapping terhadap minat belajar biologi konsep monera pada siswa kelas X MIA SMA Negeri 9 Makassar.

\section{PEMBAHASAN}

Berdasarkan tabel 3 hasil analisis deskriptif menunjukkan perbandingan skor minat belajar siswa pada kelas kontrol yang diajar menggunakan metode ceramah dengan kelas eksperimen yang ajar menggunakan metode mind mapping. Data hasil deskriptif minat belajar siswa diperoleh skor rata-rata pada kelas kontrol yaitu 82,4 sedangkan pada kelas eksperimen yaitu 91,2. Dari data tersebut menunjukkan bahwa rata-rata skor nilai pada kelas eksperimen lebih tinggi dari pada kelas kontrol. Hal ini berarti terdapat perbedaan nilai minat belajar siswa pada kelas eksperimen yang ajar menggunakan metode mind mapping dengan kelas kontrol yang diajar menggunakan metode ceramah.
Berdarkan hasil uji hipotesis minat belajar siswa menggunakan uji Independent Samples T-test didapatkan nilai Sig (2-tailed) 0,008<0,05, hal ini berarti $\mathrm{H}_{0}$ ditolak dan $\mathrm{H}_{1}$ diterima, dengan demikian dapat disimpulkan bahwa terdapat pengaruh metode mind mapping terhadap minat belajar biologi konsep monera pada siswa Kelas X Mia di SMA Negeri 9 Makassar.

Dari hasil analisis menggambarkan bahwa pembelajaran menggunakan metode mind mapping pada kelas eksperimen mampu meningkatkan minat belajar siswa dibandingkan kelas kontrol dengan menggunakan metode ceramah yang digunakan guru mata pelajaran dalam mengajar di kelas. Hal ini dikarenakan pada kelas kontrol guru lebih berperan andil dan siswa kurang dilibatkan dalam kegiatan pembelajaran. Cara guru menyampaikan materi yang tidak menarik serta siswa dituntut untuk mencatat seluruh materi yang ada dibuku paket. Waktu habis hanya untuk mencatat kata-kata yang kurang ada hubungannya dengan pokok materi dan mencatat kata yang sama yang tidak diperlukan. sehingga siswa cenderung merasa bosan dalam mengikuti pelajaran. Sedangkan meningkatnya 
minat belajar siswa pada kelas eksperimen yang diajar menggunakan metode mind mapping disebabkan karena siswa berperan aktif dan terlibat langsung dalam kegiatan pembelajaran. Siswa mendengarkan penjelasan guru secara seksama saat menjelaskan materi menggunakan metode mind mapping.

Selama proses pembelajaran berlangsung, terlihat bahwa siswa semangat dan antusias mengikuti pembelajaran, terutama pada saat pembuatan mind mapping karena setiap kelompok siswa bebas berkreasi dan berimajinasi dalam mengungkapkan idenya sendiri berdasarkan konsep, teori serta kaitannya dengan kehidupan sehari-hari yang terkait dengan materi pelajaran yang dibuatkan mind mapping.

Hasil penelitian ini menunjukkan bahwa metode pembelajaran mind mapping lebih baik di bandingkan dengan metode ceramah yang secara konvensional sering digunakan. Dengan adanya metode pembelajaran mind mapping siswa menjadi tertarik untuk mempelajari ulang apa yang telah dipelajari karena siswa karena siswa lebih tertarik untuk mempelajari ulang apa yang telah dipelajari karena siswa menulis dengan kreasi siswa masing- masing dengan beraneka simbol, gambar dan warna-warna untuk mengingat materi. Pemetaan pemikiran adalah teknik pemanfaatan seluruh otak dengan menggunakan citra visual dan prasarana grafis lainya untuk membentuk kesan. Otak sering kali mengingat informasi dalam bentuk gambar,simbol,suara,dan perasaan. Peta pemikiran menggunakan pengingatpengingat visual dan sensorik ini dalam bentuk suatu pola ide-ide orisinil dan memicu ingatan yang mudah, ini jauh lebih mudah dari pada metode pencatatan tradisonal karena ia mengaktifkan kedua belah otak cara ini juga menyenangkan, menenangkan kreatif.

Dalam proses pembelajaran memang awalnya siswa banyak yang tidak memperhatikan guru dalam memberikan materi pembelajaran, banyak yang membuat suasana kelas gaduh, dan banyak yang bermalasmalasan seakan-akan tidak mau menerima materi pembelajaran. Tetapi didalam proses pembelajaran, siswa mampu menjawab pertanyaan yang diajukan oleh guru sesuai dengan apa yang diharpakan oleh guru. Selain itu, siswa juga mampu menyelesaikan tugas dari guru. 
Meskipun masih ada siswa dalam setiap kelompok mengalami kesulitan dan membutuhkan bimbingan dan arahan dalam membuat mind mapping, dapat diatasi dengan cara guru berkeliling dalam kelas memonitor, mengavaluasi, dan melihat kegiatan kelompok. Membimbing siswa untuk menentukan kata kunci dari bagianbagian materi monera yang diajarkan, kegiatan ini membantu siswa mengatasi kesulitan dalam membuat mind mapping. Sehingga proses pembelajaran lebih menarik perhatian siswa. Siswa mampu menyalurkan ide kreatifitasnya yang dituangkan dalam bentuk catatan yang unik karena menggabungkan antara teks dengan gambar sehingga tampilannya menarik dan mudah dipahami. Hal ini sesuai dengan pernyataan Darusman (2014), bahwa mind mapping dapat meningkatkan kemampuan berpikir kreatif. Dengan adanya kombinasi warna, gambar dan cabang-cabang yang melengkung lebih merangsang secara visual. Hal ini memudahkan siswa untuk mengingat materi yang dicatat dalam bentuk mind mapping. Sehingga dengan ini metode mind mapping memperlihatkan pengaruh positif terhadap minat belajar siswa.

\section{KESIMPULAN}

Berdasarkan hasil penelitian dan pembahasan maha dapat disimpulkan bahwa Ada pengaruh metode Mind Mapping terhadap minat belajar biologi konsep monera pada siswa Kelas X di SMA Negeri 9 Makassar, dilihat dari hasil uji hipotesis menggunakan uji analisis Independent Samples T-test dimana diperoleh nilai Sig (2-tailed) $0,008<0,05$.

\section{UCAPAN TERIMA KASIH}

Ucapan terima kasih yang tak terhingga kepada bapak Drs. Supardin, M.Pd selaku kepala sekolah SMA Negeri 9 Makassar dan ibu ST. Kahfiah S.Pd selaku guru mata pelajaran biologi yang selalu memberikan ijin penelitian, bimbingan dan motivasi kepada penulis selama melakukan penelitian.

\section{DAFTAR PUSTAKA}

Abtholulbihar, A. (2018). Pengaruh Metode Mind Mapping Terhadap Minat dan Hasil Belajar Siswa Kelas VIII SMPN 2 Watulimo. Skripsi. Tidak diterbitkan. Fakultas Tarbiyah dan Ilmu Keguruan IAIN Tulungagung.

Darusman. (2014). Penerapan Metode Mind Mapping (Peta Pikiran) Untuk Meningkatkan Kemampuan Berpikir Kreatif Matematik Siswa SMP. Infinity 
Journal (Online).Vol. 3, No. 2

(http://e-

journal.stkipsiliwangi.ac.id/inde

x.php/infinity/article/view/61,

diakes 9 Oktober 2019).

Mulyatiningsih, E. (2014). Metode Penelitian Terapan Bidang Pendidikan. Bandung: Alfabeta.

Nazliah, R., Harahap, R.D., \& Hasibuan, E.R. (2019). Pengaruh Model Pembelajaran Mind Mapping Terhadap Hasil Belajar Siswa Pada Materi Respirasi Di Kelas XI SMA Negeri 2 Bilah Hulu. Jurnal Biolokus (Online). Vol. 2, No. 2 (http://jurnaltarbiyah.uinsu.ac.id/ index.php/biolokus/article/view/ 534, diakses 9 Oktober 2019)

Ridwan. (2009). Metode dan Teknik Menyusun Proposal Penelitian. Bandung: Alfabeta.

Sugiyono. (2016). Metode Penelitian Pendidikan (Pendekatan Kuantitatif, Kualitatif dan $R \& D)$. Bandung: Alfabeta.

Swadarma, D. (2013). Penerapan Mind Mapping dalam Kurikulum Pembelajaran. Jakarta: PT Gramedia. 